\title{
Phenomelogical Study on the Financial Performance and Accountability of Special Autonomy Fund Management in Education Sector at Papua Province
}

\author{
John Agustinus \\ Promoter: Ubud Salim. Co-promoter: Bambang Subroto and Co-promoter Eko Ganis Sukoharsono.
}

\begin{abstract}
Abstrac: Initially, Special Autonomy was perceived as huge gift for Papua people. Papua people have high expectation that Special Autonomy will elevate their living standard. Morover, in Undang-Undang Otonomi Khusus, emphasize on the basic rights of Papuans should be met. Furthermore, the vast amount of Special Autonomy fund causes even higher expectation. Yet, the fact says differently; almost all of the informants stated single voice that the perceived fact is not as high as what they expected. Fenomenology research is a study which is conducted at particular setting in a real live (natural setting) to investigate and understand phenomena. The findings related to financial performance reveal a concept as a set of law and regulation that shapes Special Autonomy fund management of Papua Province. The set of Special Autonomy Fund Management Regulation creates a financial model in special autonomy era consisting of four management functions that are strategic financial planning, the implementation of education program based on the education budget as mandated in Undang-Undang Otonomi Khusus, fund utilization report that has been made, and control/audit on the special autonomy fund management in education sector. Building compliance and control system implementation to be a culture is a necessity in financial management. Therefore, the implementation of compliance and control by audit organization toward financial management functions will be able to achieve value for money (effectiveness, efficiency, and economics) of the education budget. To more strengthen the culture of special autonomy of Papua, it needs to build knowledge and understanding on the financial performance as mandated in UU Otonomi khusus toward the government officers of Papua Province who manage the fund as well as construct a culture to manage the Special Autonomy for Papua Province.
\end{abstract}

Keywords: Finance, Accountability, Special Autonomy

\section{Introduction}

Special Autonomy of Papua Province basically is a wider authority for Papua people and government to administer and manage their region in the frame of Indonesia Republic. Wider authority means higher responsibility for Papua government and people to establish their governance and manage the utilization of Papua Province's natural resources for the Papua people welfare. This authority also means the right to empower its social and cultural potentials as well as economics potential of Papua people, including the effort to deliver equal role of the native Papua through their cultural/ethnic, religion, and women representatives.

In general, there are four basic principles in Undang-Undang No.21 / 2001 about Penyelenggaraan Otonomi Khusus Bagi Provinsi Papua that are

1. The regulation of authority between central government and provincial government of Papua as well as the authority implementation at Papua Province which is conducted with some particularities.

2. The legitimate and respect on native Papua's basic rights as well as the strategic and fundamental empowerment

3. Establish good public governance that is characterized by:

a. Higher participation of the people in planning, implementation, and control of government governance as well as the implementation of development that involves cultural/ethnic, religious, and women representatives.

b. Development implementation is directed optimally to fulfill the basic needs of native Papua particularly and Papua people generally.

c. Transparent and accountable government governance and development implementation for the society.

4. Delegation of authority, task, and responsibility that is firm and clear as legislative, executive, and judicative authority holder as well as Majelis Rakyat Papua as the cultural representative of native Papua which gets particular authority.

The principle of special autonomy for Papua province is meant to achieve fairness, equality in law supremacy, respect on human rights, acceleration of economics development, enhancement on social welfare and prosperity of Papua people, in attaining equality and balance with other provinces.

The implementation of Special Autonomy is obstructed by the unfinished implementation regulation of UU No. 21/2001. To implement the special autonomy, it needs a set of provincial regulation (peraturan daerah 
propinsi/ perdasi) and special regional regulation (peraturan daerah khusus/perdasus) that become the implementation regulation of UU No. 21/2001. Yet, so far, only one Perdasus is stipulated, while some others of fundamental Perdasi/Perdasus are not yet fixed: such as those which regulate special authority for provincial or regency/city government to establish the implementation of special autonomy as well as those which rule the development of prioritized sectors. In general, it happens because the slow process of legislation and lack of coordination among provincial government, provincial House of Representatives, and MRP. In practice, the implementation of special autonomy is mostly conducted using other less-binding law and regulation since it is not legitimated by provincial house of representative and MRP.

The special autonomy fund gives significant contribution for Papua provincial and regency/city government. For the period of 2004-2008, totally the special autonomy fund contributed $21.6 \%$ of the total revenue of the whole local governments of Papua province. For the provincial government, as subtracted by the allocation for regency/city, special autonomy funds provided almost half contribution (42\%) of the total revenue. For regency/city government, during the same period, special autonomy fund contributed $12 \%$ of the total revenue.

Accountability means responsibility to generate a trustworthy audit through authority distribution on the local/regional government to prevent centralization of authority as well as create peer check and balance system. Moeller (2009), Anderson and Narus (1990), Child and Faulkner (1998), Das and Teng (1998), Zaheer and Venkatraman (1995) proved that empirically there is a direct relationship between accountability and participation to financial performance. Those decision makers such as manager, director, and the business owner (stockholder) that are trusted by their network or business partner to will be able to enhance its financial performance, particularly in achieving good return. Furthermore, the manager, director, and business owner that are able to arrange partnership with their network are also able to maintain the financial performance to the positive direction.

Moeller (2009); Anderson and Darus (1990); Child and Faulkner (1998); Das and Teng (1998); Zaheer and Vankatraman (1995) tried to find the role of trust and participation on financial performance. Moeller (2009) did not search for the consequence of the main value of trust on financial performance but the main value of trust is the accountability variable. This research fills the research gap of Moeller (2009) by adding accountability variable. It is based on Pekman's (1998), Penrose's (1959), and Barney's (1991) research stating that public accountability has long term effect on financial performance. This is based on the statement of Wernerfelf (1984); Teece 1998); D'Aveni (1995); as well as Das and Teng (2000) who all mentioned that trust is inseparable with the accountability that is built to achieve positive objective of the financial performance.

Based on the BPK's (Badan Pemeriksa Keuangan/ Financial Audit Agency) audit in 2008, the allocation of special autonomy fund for health service sector reached $10.96 \%$; while for education sector it was only $6.2 \%$. The allocation on both sectors were still below the standard as mandated in UU No. 2001 which mentions that it should be $15 \%$ and $30 \%$ respectively for health service and education.

The background that causes problems on financial performance of Papua Province is stated during a seminar entitled "Financial Transparency and Accountability at Papua Province" which was held by Lembaga Penguatan Masyarakat Sipil Papua (The Instituion of Papua People Empowerment) in the discussion forum of Hasil Analysis APBD Propinsi Papua (Papua Province's Revenue and Expense Budget Analysis Result) (ICS, 2009).

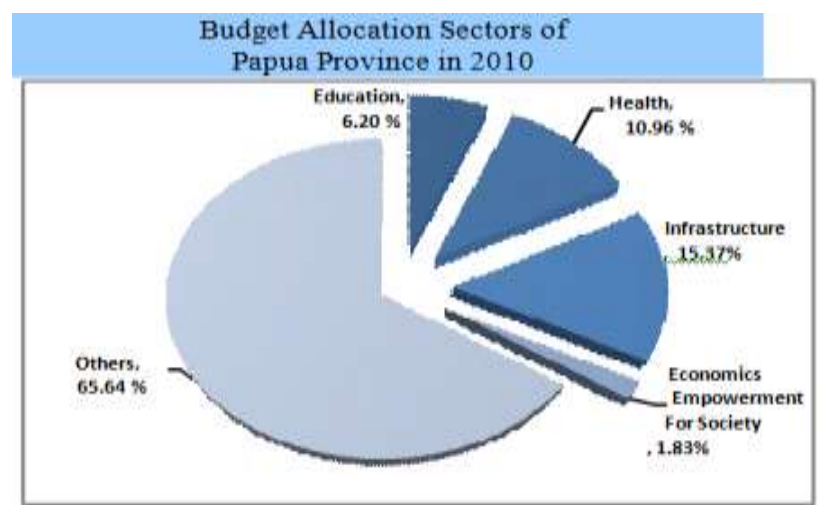

Source: Audit Report on the Special Autonomy Fund Management; BPK, 2010

“...From the perspective of data/information presentation in the APBD 2009's document, there is shrinkage as compared to APBD 2007-2008. The fund resource of each program was not presented whether it comes from special autonomy fund, PAD, or balance fund (DAU, DBH, and DAK). The budgeted programs are not enclosed with some detail explanations related to the factual cost and unit cost so that it is difficult to calculate the 
feasibility and rationality of each allocated fund. Such data presentation opens a chance to be abused by the fund management officer. Some of the budgets listed in the APBD 2009 explanation's document are different from the total amount listed in the recapitulation document. It means that the validity and accountability of the data on the APBD 2009's documents is doubtful..."

\section{Budget for Education of Papua Province in 2006-2010}

\begin{tabular}{|c|c|c|c|c|c|}
\multicolumn{2}{|c|}{ (in Billion Rupiah) } \\
\cline { 4 - 6 } Year & $\begin{array}{c}\text { ProvincialAP } \\
\text { BD's } \\
\text { Value }\end{array}$ & $\begin{array}{c}\text { Special Autonomy Fund } \\
\text { for Province (40 \%) }\end{array}$ & Total & \% to APBD & $\begin{array}{c}\text { \% to } \\
\text { Provincial } \\
\text { Special } \\
\text { Autonomy } \\
\text { Fund }\end{array}$ \\
\hline 2006 & $3.918,02$ & $1.264,35$ & 198,27 & 5,06 & 15,68 \\
\hline 2007 & $5.856,89$ & $1.565,14$ & 203,49 & 3,47 & 13,00 \\
\hline 2008 & $5.449,04$ & $1.859,53$ & 228,72 & 4,19 & 12,30 \\
\hline 2009 & $5.142,08$ & $1.043,92$ & 231,15 & 4,49 & 22,14 \\
\hline 2010 & $5.124,53$ & $1.043,92$ & 244,40 & 4,77 & 23,41 \\
\hline
\end{tabular}

Source: Papua's APBD 2006-2009; Papua's RAPBD 2010; and Financial note of Papua's RAPBD 2010 (processed)

From the table above, it can be seen that budget allocation for education increased from Rp. 231.15 billion in 2009 becoming Rp. 244.40 billion in 2010 (about 5.73\% increase). This rise happened on both direct and indirect expenditures. Indirect expenditure rose from Rp. 27.11 billion in 2009 becoming Rp. 34.21 billion in 2010 (nearly 26.19\% increase). Meanwhile the direct expenditure grew from Rp. 203.45 billion in 2009 to Rp. 210.19 billion in 2010 (approximately $3.31 \%$ increase). From the expenditure budget composition, it roughly informs that the education budgeting in RAPBD (Regional Revenue and Expense Budget Plan) of Papua in 2010 had public orientation.

Referring to the law and regulation that set the amount of education budget allocation in APBD, as previously mentioned, the education budget of Papua province in 2010 was only $6.11 \%$ of the total APBD or it was just $11.99 \%$ from the special autonomy fund. It violated UUD 1945, UU Otonomi khusus, UU No. 20/2003, PP No.48/2008, and Perda No.5/2006. It means that Papua's APBD in 2010, which defined 4.77\% allocation for education, did not have binding legal force (that happened as well on the Papua's APBD in 2006-2009). Whereas, if it refers to UUD 1945, UU No. 20/2003, and PP No. 48/2008 which defines minimum $20 \%$ budget allocation for education from total APBD, then the education budget of Papua in 2010 would have reached Rp. 1,024.91 billion for its minimum amount (or Rp 1.02 trillion). If it refers to Perda No.5/2006 which defines minimum $30 \%$ from total special autonomy fund, the education budget allocation of Papua's APBD in 2009 were at least Rp. 782.94 billion.

\section{Research Focus}

Regional autonomy, particularly special autonomy of Papua Province, is the central government's commitment to reach equal development in Papua compared to other provinces, enhance Papua people welfare, as well as the right and pride of Papua people. Fund transfer policy of the central government to Papua Province, both equality and special autonomy funds have quite huge portion as compared to the average among the other provinces in Indonesia. Therefore, the main task of government as the biggest public organization is to create society welfare since welfare is a multi-complex concept. Government as the special autonomy fund manager is demanded to manage the finance with accountable and transparent principles.

Education becomes the focal priority and gets huge fund to develop education in Papua Province. The problem is that during ten years implementation of special autonomy in Papua Province, the education condition is still low so that the guarantee of right and obligation of each citizen to obtain and join education are not yet sufficient, such as:

1) Low equality of education chance for inter-region, for different income distribution, and among gender.

2) Low quality and relevance of education since the curriculum is not related to the needs on the job vacancy availability, low quantity and quality of teacher, as well as limited facilities and infrastructure in education; and

3) Weak education management establishment both for formal and society based educations.

Financial performance basically is a system of arrangement and management of regional budget which is oriented to achievement or performance result. The performance must reflect public service efficiency and effectiveness; it means that is should be oriented to public interests. The basic principles to manage special autonomy fund are transparency, accountability, and value of money. 


\section{Research Problems}

There is a huge special autonomy fund available; yet, the education sector is not able to enhance the quality of education in Papua Province. It is even low still; therefore, the problems examined in this research are rational choice research about what special autonomy management officers will decide by using questions:

1. How are the financial performance and the accountability of special autonomy fund in education sector of Papua Province? Is it either able to improve education quality?

2. How can the society get the benefit of special autonomy fund for education sector?

3. How are the plan, implementation, report, and audit of special autonomy fund management in education sector?

\section{Financial Performance}

\section{Theoretical Foundation}

Regional development is inseparable with the respective institutions that manage it. Each region has distinctive procedures in managing their development that causes different performance. Performance appraisal based on the periodical operation activity of an organization, part of the respective institution of the government based on the target, and the standard that has been previously determined. Through financial performance, people (the society) will be able to assess the performance of government governance. Organization performance appraisal can be done by conducting financial analysis. Financial analysis much depends on the provided information as stated in the financial report. One of the functions of financial report is providing information related to financial performance.

Accounting information is very useful to asses a manager's performance accountability. Since performance appraisal is basically an appraisal of someone's behavior in conducting the role he has to achieve organization's objective. The other possibility is using accounting information as well as non-accounting information to asses a manager's or a leader's performance in an organization. Based on the Scribner-Bantam English Dictionary in Sedarmayanti (2004:175-176), the definition of performance is: the job outcome that can be achieved by an individual or a group of people in an organization, based on the authority and responsibility to achieve the organization's objective in legal way, not violating the law, and considering moral and ethic".

Based on Hayadi and Kristiani (2007:103), they define performance as follow:

"Performance is a description of the level of activity or program implementation as the effort to achieve the objective, vision, and mission of an organization"

According to Jumingan (2006:239), he explains the definition of performance as follow:

"Performance is a description of the echievement that an organization wants to attain in its operation activity related to financial, marketing, fund collection and distribution, technological and human resource aspects".

\section{Accountability}

Accountability, is attitude and behavior of decision maker in public, private, and civil society sectors who is responsible for the job he has conducted to the public and stakeholders (Halim, 2008:61)

Halim (2008:64-65) explained that the implementation of regional autonomy altogether with the intense public's demand on the good public governance results in the implication of regional financial management reorientation. There are three reasons why regional financial management re-orientation is needed. First, the delegation of authority and task to provincial government that affects the recent practice of regional financial management is proven to be less-able to support good governance attainment. The most important new paradigm that should be considered in the spectrum of "delegation of authority to regional government" is that regional financial management must be directed to local bigger people interests and higher social welfare. The emphasize is not only on the proportion of budget allocation but also the range of benefits and the frequency of society's participation.

\section{Method}

Fenomenology research is a study which is conducted at particular setting in a real live (natural setting) to investigate and understand phenomena: what happens, how it happens, and how it happens. Therefore, qualitative research is based on the "going exploring" concept that involves in-depth and case oriented study on several cases or single case (Weber, 1960). Qualitative research aims to make a fact to be understandable and, if possible (based on its research model), produce new hypothesis.

In this research, it studies financial performance and accountability of special autonomy fund management. It is conducted by gathering information of the respective parties, particularly the regional government and the society that receive the fund and benefits from the special autonomy fund. For the supporting study, the information from the decision makers from Papua House of Representatives Members and Department of NGO in Papua that are competent to provide information is also collected. Thus, the analysis unit 
of this research consists of individual (officer) of Papua Province government and NGO. The location of institution and NGO organization is limited to the capable experience and insight in understanding financial performance when the special autonomy fund is established in Papua Province.

\section{Field Data Findings}

The analysis technique used is phenomenological analysis as proposed by Weber (1960); phenomenology is related to the rational action concept by analyzing the meaning hidden behind the act of individual which enforces the social symptoms to be real. Also, it reveals why special autonomy fund management abuse occurs.

The first informant provided some statements related to special autonomy fund management; it obtains a meaning that

“...education programs have already complied the policy direction. Government is directed to the society's education quality enhancement. The government has provided sufficient facilities and infrastructures of health. Yet, to confess, the enhancement is not yet optimally meaningful in quality to improve people's status as well as not yet optimum to provide real impact on the education service satisfaction, particularly for the low level of social class..."

As continuing the interview to the second competent informant related to education development which is the focal priority of special autonomy, it obtains a meaning as follow:

"...education sector becomes a crucial point in the policy framework and development strategy. To achieve an education quality that is able to generate professional human resource, the policy is directed to create education equality by opening the chance as wide as possible for all society members, especially for nine-year compulsory study program by utilizing physical/non-physical facilities and infrastructures also by adding more number of teachers and more qualified teachers. There are some aids provided by the government, such as low-cost education, scholarship, operating fund aid for schools, etc."

The Development of Special Autonomy Fund in 2002-2010

\begin{tabular}{|c|l|c|}
\hline Year & Special Autonomy Fund (Rupiah) & Growth (\%) \\
\hline 2002 & $1,382,300,000,000,--$ & - \\
\hline 2003 & $1,527,011,000,000,-$ & 10.5 \\
\hline 2004 & $1,642,620,000,000,-$ & 7.6 \\
\hline 2005 & $1,775,310,000,000,-$ & 8.1 \\
\hline 2006 & $2,913,300,000,000,-$ & 64.1 \\
\hline 2007 & $3,295,630,000,000,-$ & 13.1 \\
\hline 2008 & $3,590,120,000,000,-$ & 8.9 \\
\hline 2009 & $2,609,790,000,000,-$ & -27.3 \\
\hline 2010 & $2,694,650,000,000,-$ & 3.3 \\
\hline Amount & $\mathbf{2 1 , 4 3 0 , 7 3 1 , 0 0 0 , 0 0 0 , -}$ & \\
\hline
\end{tabular}

Source: Papua Provincial Government in 2011 and BPK's Audit Report in 2010

The second informant's statement is in resemblance with the meaning obtained by the researcher during his interview with the third informant whom has competence in education field. Researcher identified similar meaning on the third informant's statement as follow:

“...It is true that based on the Special Autonomy era, as mentioned in Undang-Undang Republik Indonesia No. 21/2001 about Otonomi Khusus bagi Provinsi Papua, article 34 paragraph 3 letter e, it is firmly stated that special revenue as the consequence of Special Autonomy implementation is equal to two percent from the total National General Allocation Fund (Dana Alokasi Umum Nasional), which is mainly for financing education and health service sectors. Next, it is mentioned that the $30 \%$ of Special Autonomy fund should be allocation for education funding..."

The identified themes from the informant's perception are:

(1) The amount of education budget allocation can be seen from the sum of APBD (regional government revenue and expenses) and special autonomy fund.

(2) The compliance of provincial government on the applicable law and regulation which becomes the foundation to allocate and manage education budget

(3) The alignments of provincial government and regional house of representative as the political decision maker in the process of arrangement and appointment of $A P B D$ and special autonomy fund to fund the education sector

(4) Provincial government's priority programs in education sector and the amount of supporting fund that is provided in the APBD document to implement the intended programs. 
(5) Abuse and inefficiency indications in the budget utilization as Abuse and Inefficiency of Financial Allocation Indication in education and solution which is offered to overcome the abuse and inefficiency.

Based on the BPK's audit report on the Financial Statement of Papua Province in 2005-2006, BPK found some indications of abuse in utilizing special autonomy fund in 2005 for Rp. 27.51 billion, in 2006 for Rp.77.56 billion. Particularly for education sector's fund that was managed by Education Department of Papua Province in 2005-2007, BPK found total abuse that caused loss of regional finance for Rp. 4.81 billion. The abuse occurred in the form of non-accountable expenditure (no attached valid payment receipts), inefficiency in goods and service procurement, and physical project implementation which is not matched as the contract appointment. The ICS and FITRA Jakarta analysis team cannot obtain new information about the development of this problem related to how this problem is solved.

\section{The Benefit Of Special Autonomy}

The researcher identifies the meaning of the benefits obtained by Papua people from special autonomy and the consequences of public requirement which say that special autonomy has not yet touched the public interest. Some statements of the informants from the Papua people are identified as follow:

Informant A1

“...Special Autonomy is not yet able to solve education problem for Papua people since there is no prove on the distinct improvement to a better direction: (1) the alignment to native Papua until the inland area is still very least, (2) the number and quality of elementary and middle school teachers are still limited, particularly for Natural Science subject. It makes teachers do extra role by teaching some subjects. Teacher's prosperity is still inadequate so that some of them take other side job as motorcycle taxi driver in the evening to earn more money. This brings them to fatigue and spiritless in taking their responsibility as their function and task..."

\section{Informant A2}

Resistance of the society occurs related to the implementation of Special Autonomy since the implementation on the certain prioritized sectors is not quite obvious for its development. It does not make apparent improvement on education, health, economics of people, and basic infrastructures. It has been 9 years of the Special Autonomy implementation; yet there is no distinct outcome that causes doubt from the people that education, health, economics of people, and infrastructures do not significantly get enhanced.

\section{Data Analysis And Propositions}

The researcher identifies some law and regulations about accountability in Special Autonomy are of Papua Province; the accountability regulation identification results are as follow:

1. UU No 21 Tahun 2001, Pasal 67 ay 1, In establishing good governance government that is clean, respectful, transparent, and accountable, it needs doing law monitoring, political monitoring, and social monitoring.

2. Perda No 5 Tahun 2006, Pasal 69 ayat 1, Local government functionally conducts auditing on Education establishment. Pasal 70 ayat 1 Education board conducts auditing on the plan and the implementation of education program.

3. Perdasus No 1 Th 2007, Pasal 21 It managed based on transparent, accountable, responsible principles that is free from corruption, collusion, and nepotism. Pasal 26 ayat 2 The audit covers planning, implementation, and responsibility in financial matters. Pasal 27 ayat 1 Provincial government, Papua House of Representatives (DPRP), and the society monitor the utilization of the income as the consequence of Special Autonomy implementation.

From the set of law and regulation above, it derives a theme that accountability compliance is government obligation to provide responsibility or answer and describe the performance and special autonomy fund management act to the party that holds the authority and right in asking for description or responsibility during one year financial period. BPK RI 2002-2010 mentioned the accountability definition for Papua Province:

"....accountability is responsibility or answer and describes the performance and act during the process of planning, implementing, and controlling..." 


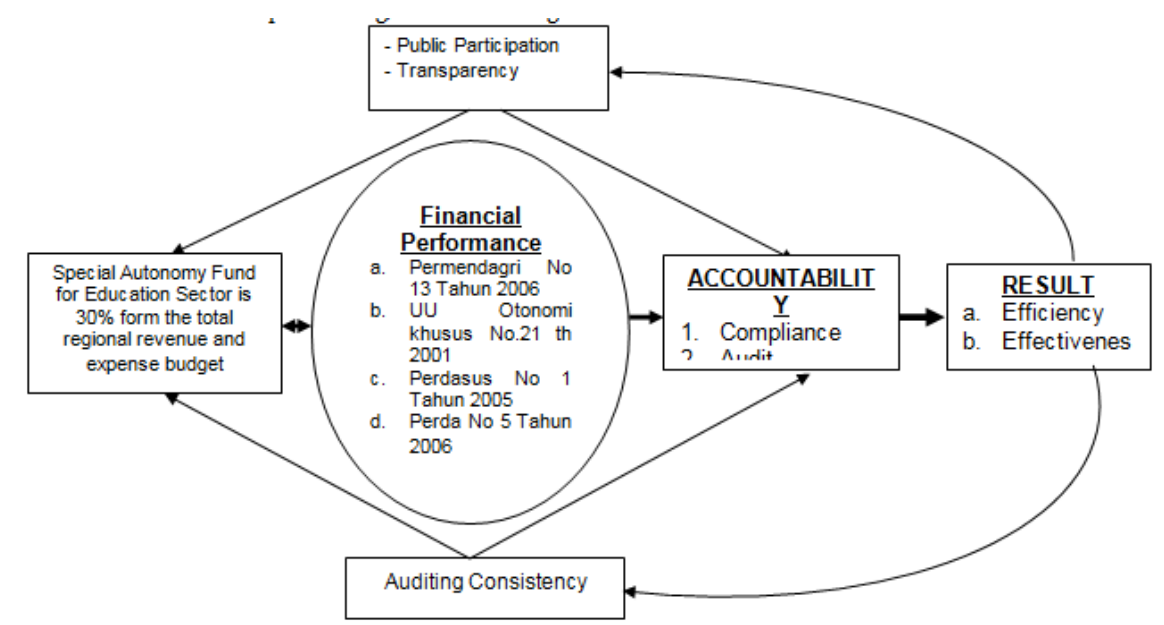

Figure 1. Research Model

From the financial management study, accountability and benefit of special autonomy are derived from premises that are presented on the research model. Figure 1 describes the inter-relationship of the themes in detail as summarized in Table 1.

Based on the Figure 1, we can see the model of special autonomy fund for education sector as the Province of Papua gets special autonomy fund for 30\% from the Papua Province's Regional Budget Revenue and Expenses (APBD/Anggaran Pendapatan dan Belanja Daerah). It supposes, as the huge amount of fund availability for education sector, that education must make quality enhancement. Since there is a discrepancy in education sector at Papua Province and no quality enhancement occurs on the exact sector, then the financial performance for education management in Papua Province have four strength indicators to improve the education sector such as Undang-undang Otonomi khusus No 21 Tahun 2001, Permendagri No 13 Tahun 2006, Perda No 5 Tahun 2006 and Perdasus No 1 tahun 2005. Thus, if those four indicators to manage education sector is implemented in compliant principle, then the education sector of Papua Province will be better in the future. Besides, it needs tight audit and control from the Financial Audit institution as well as from public on the implementation of the autonomy on education sector. By implementing the tight and consistent audit and control on each year, it will reduce the authority and mechanism abuse in managing special autonomy fund in education sector.

\begin{tabular}{|c|c|}
\hline \multicolumn{2}{|l|}{ Minor Proposition } \\
\hline Minor Proposition & $\begin{array}{c}\text { Its relationship with special } \\
\text { autonomy fund management }\end{array}$ \\
\hline $\begin{array}{l}\text { Special Autonomy Regulation and the set of government regulation is the } \\
\text { financial performance to manage special autonomy fund }\end{array}$ & $\begin{array}{l}\text { Special Policy } \rightarrow \text { Enhancement } \rightarrow \\
\text { Special Autonomy Law } \rightarrow \text { Fund } \\
\text { Management } \rightarrow\end{array}$ \\
\hline $\begin{array}{l}\text { The implementation of special autonomy regulation in Papua province } \\
\text { provides authority for regional government to enhance education quality in } \\
\text { Papua province }\end{array}$ & $\begin{array}{l}\text { Knowledge, insight, and worry of } \\
\text { the society } \rightarrow \text { successfulness and }\end{array}$ \\
\hline $\begin{array}{l}\text { The special autonomy fund management should bring huge contribution to } \\
\text { the society }\end{array}$ & education quality $\rightarrow$ accountability \\
\hline $\begin{array}{l}\text { Huge fund management and people's worry on the fund management } \\
\text { become the basic reference of the society to judge the government related } \\
\text { to its financial accountability }\end{array}$ & $\begin{array}{l}\text { Compliance, fund management, } \\
\text { effectiveness and efficiency, as well } \\
\text { as the benefit received by society }\end{array}$ \\
\hline $\begin{array}{l}\text { Accountability that is expected by Papua people defines the successfulness } \\
\text { in managing the special autonomy fund }\end{array}$ & $\begin{array}{l}\rightarrow \text { the amount of special autonomy } \\
\text { fund, education quality, audit } \rightarrow\end{array}$ \\
\hline $\begin{array}{l}\text { Knowledge and understanding of government officers on the meaning of } \\
\text { special autonomy fund and how to run the UU Otonomi khusus defines the } \\
\text { development successfulness. }\end{array}$ & $\begin{array}{l}\text { financial performance } \rightarrow \\
\text { accountability }\end{array}$ \\
\hline $\begin{array}{l}\text { regional government accountability in managing special autonomy fund } \\
\text { defines the compliance to enhance education quality }\end{array}$ & \\
\hline $\begin{array}{l}\text { Failure to improve education quality will provide accountability to } \\
\text { regional government and provide reference to improve special autonomy } \\
\text { fund management compliance. }\end{array}$ & \\
\hline $\begin{array}{l}\text { The compliance to run a set of Special Autonomy Law, accountability and } \\
\text { fund management related to education quality and benefits for the society. }\end{array}$ & \\
\hline
\end{tabular}


Based on the mapping in the Minor Proposition table, it formulates some major proposition as follow:

1. UU Otonomi khusus, peraturan pemerintah daerah and compliance define financial performance of special autonomy fund management.

2. The compliance, control, and responsibility on the special autonomy fund determine the accountability of special autonomy fund management.

3. Knowledge related to the education and experience as the foundation to manage the fund effectively and efficiently will provide benefit to the people of Papua Province.

\section{Discussion}

The different meaning of financial performance and financial achievement in this research results on the finding of an inefficiency and ineffectiveness phenomenon of special autonomy' financial performance; it also finds the different accountability of special autonomy fund management. It is illustrated in the following figure:

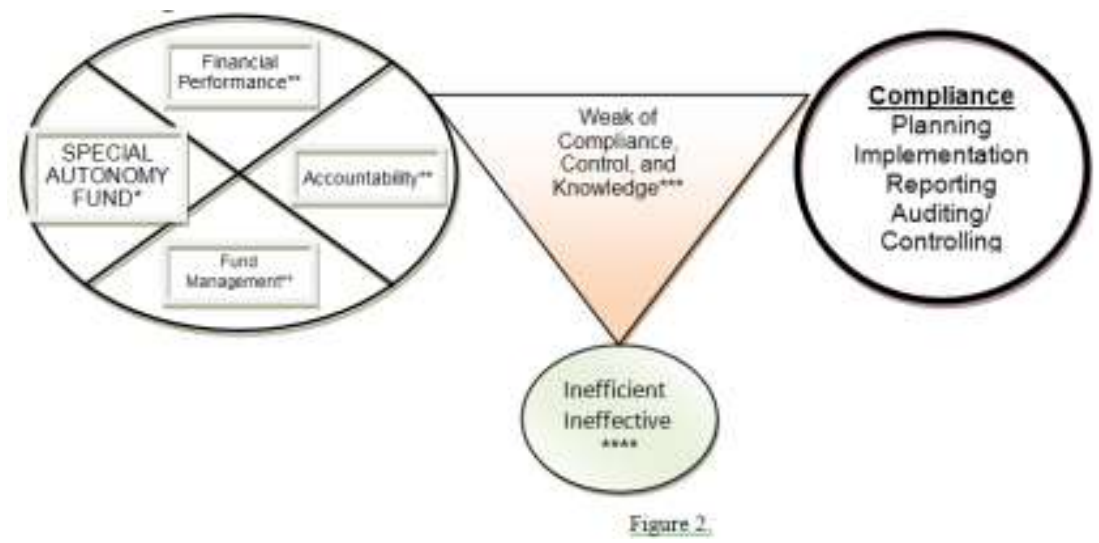

Illustration on the Inefficiency and Ineffectiveness of Special Autonomy Fund Management

Source: Processed based on several references for this dissertation*) Program of UU Otonomi khusus, Perdasi No 6 2006; **) Accountability Report of Papua Province's Governor in 2010;***) Informants; **** BPK RI Audit Report in 2008, 2009 and 2011

As illustrated in Figure 2 above, it explains the inefficiency and ineffectiveness of special autonomy fund management; thus, it formulates the answers of the research questions that financial performance and accountability of special autonomy fund management in education sector in Papua Province is not yet able to enhance education quality. The society also has not got the benefits of special autonomy fund in education sector. From the obtained themes and reduction step, one of the weaknesses that occur is about the compliance and control. Control is an integral part among the other stages in arranging and reporting APBD. Theoretically, audit is needed on each stage, not only on evaluation stage (Mardiasmo, 2001). The control conducted by house of representative members is started during the process of APBD arrangement, legalization, implementation, and accountability process. Alamsyah (1997) mentioned that the aim of APBD audit is (1) to control that the arranged budget is implemented, (2) ensure that the implementation of APBD is relevant with the defined budget, and (3) ensure that APBD implementation is accountable.

Since the regional autonomy runs in Indonesia Republic, from that time until recent time, several law and regulation have been produced. Those regulations consist of law, government rule, president decree, ministry decree, etc. All are made to ensure that the autonomy implementation can be well-established. As we know, the most essential part of regional autonomy is on the financial matters. Financial matter is the most important key that define the success or failure of the regional autonomy implementation on the provinces in Indonesia (Halim, 2002).

Kadmasasmita (2007: 9) and Mardiasmo (2007: 29) explained that to better implement the concept of value for money, the National financial arrangement reformation requires the implementation of value for money concept, or more well-known as $3 \mathrm{E}$ concept (economics, efficient, and effective). Therefore, in this reformation, the government is asked to always implement the $3 \mathrm{E}$ concept as seeking for fund and utilizing the fund. It encourages the government to put its effort to consider each cent/rupiah as they obtain and utilize the money. The attention goes to the relationship between input-output-outcome.

Special autonomy regulation (UU Otonomi khusus) and other set of regulation rule regional financial management of Papua Province, Mulyadi (2005), Sucipto (2007), Jumingan (2006), and Sutrisno (2009). As there is additional fund form special autonomy, the financial management must refer to and comply the applicable law and regulation Mulyadi (1997), Halim (2008). It expected that by implementing financial management based on the law and regulation, it will achieve effectiveness and efficiency to program attainment. 
Special autonomy fund given to Papua has affirmative action meaning when this fund must be utilized to support the acceleration and enhancement program for Papuan native for being left behind as compared to other provinces (Sumule, 2002). Knowledge on the meaning of affirmative action must be comprehended by the financial management officers; understanding the affirmative action is much needed since the management of special autonomy fund is different from common regional autonomy financial management so that it demands particular financial management mechanism based on the strategic budgeting plan or based on the special autonomy mandate (for education and health services).

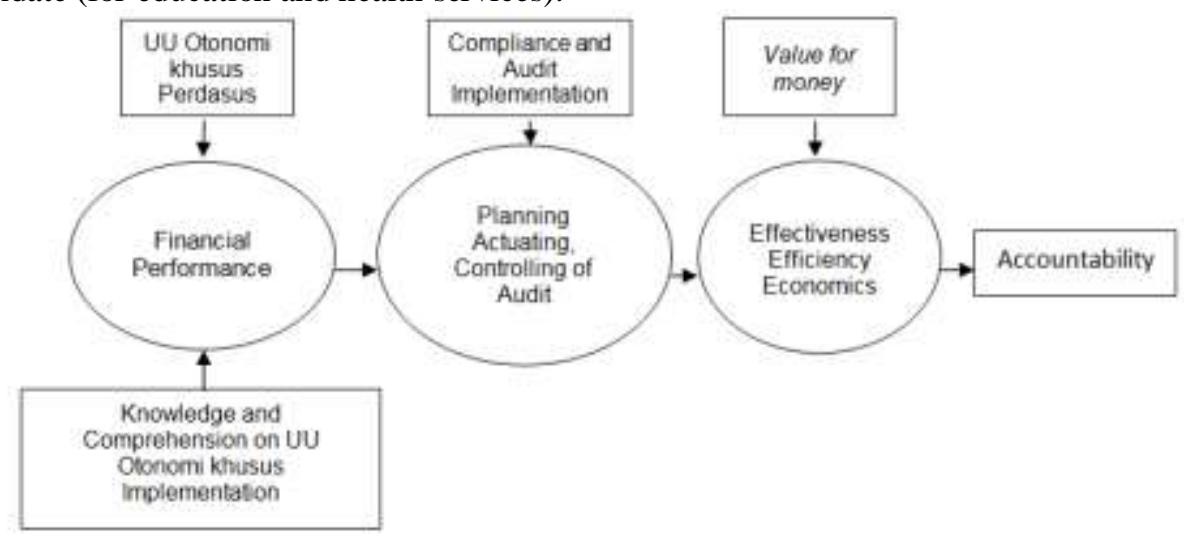

Figure 3

Financial Performance and Accountability Model

Source: Processed based on the several references of this dissertation; the main source are BPKP (2007:3), BPK RI (Financial Audit Agency of Indonesia Republic), and Informants

Knowledge and comprehension affect performance; it supported by the Supoyo's research (2006:154) which explained that knowledge influences performance. Thus, financial performance which is performance achievement as well as efficiency and effectiveness attainment must be supported by law and regulation and also the knowledge on special autonomy meaning. The implementation of program must be based on the priority. The special autonomy fund utilization report must correspond with the provided fund and run the audit function on the special autonomy fund management as mandated by law and regulation. From the audit function, the management of special authority fund will reveal its compliance on the principles of law and regulation of Papua Province's financial management.

From the tight audit and control and mechanism compliance on the financial management based on the special autonomy regulation, it is expected to achieve maximum effectiveness and efficiency; therefore, special autonomy financial management officers should be responsible as well as able to answer and describe the financial performance toward the institution which has the right to ask for explanations and accountability report to make it well-accepted. To achieve maximum financial performance, the special autonomy financial performance standards should be implemented and become organizational culture in financial management to achieve financial accountability (Supoyo, 2006)

\section{Conclusion}

This research provides some findings that are not yet revealed by former research as well as delivers new concept of thought; those findings are:

1a. Financial performance is the achievement level in regional finance consisting of the region's revenue and expenditure by using the pre-determined financial system through some policy or regulation during one budgeting period. A set of law and regulation in special autonomy financial management shapes the mechanism of special autonomy financial management.

b. The special autonomy fund management which is oriented to performance demonstrates performance accountability. Performance accountability is the manifestation of Papua provincial government's obligation to be accountable for the achievement or failure in the implementation of special autonomy fund management to attain the periodical goal and objective that are measured some performance indicators. Papua province is able to be responsible for the given special autonomy fund and able to provide explanations on the result and achievement as mandated in the law and regulation of special autonomy.

2. Individual's decision as an organization member to get involved in particular system and have greater role to achieve performance is affected by his perception about reality that he understands. Special Autonomy fund management officers are individuals that have role to achieve the performance. Therefore, knowledge and insight that special autonomy is an affirmative action is absolutely needed to make them more involved and have greater role to achieve the objective. 
3. One of the main functions of financial management is compliance function. Implementing special autonomy fund management in compliant to the applicable law and regulation will create effective and efficient financial performance. Compliance function should be also implemented in financial management model including financial planning (budget), program implementation, financial report, as well as strict control to make the outcome of the financial management model from the plan to report stages is compliant to the applicable law and regulation. It makes special autonomy fund brings high benefit to the society. Particularly for education sector, as the priority sector mandated in the Special Autonomy Law, then the fund allocation of special autonomy should be managed to achieve better quality enhancement of the education sector.

\section{Research Limitation}

During interview and discussion, informants and discussion participants often provided information and statement related to political issues as the dominant answers. Political issue indeed defines the financial management of Papua Province; therefore, political issue in this research is reduced and processed as the supporting references of this research.

Some limitations of this research are as follow:

1) Severally get some dispositions to meet other informants who are competent in Special Autonomy financial management theme.

2) In the form of annual accountability report;

3) Get guidance book to manage special autonomy fund and other references related to the topic

This phenomenon brings theme for further research about the behavior of financial management officers. Regional financial management which is oriented to performance demands decentralization; by decentralization of regional financial management, it will be able to enhance the managerial role of the regional financial management officers.

\section{SUGGESTION}

Accountability implementation requires strong commitment of the governor and all staffs in the related institutions. They should assure the utilization of resources which is consistent with the applicable law and regulation. It should confirm the goal objective achievement level as well as the obtained result and benefit/advantage. It must be truthful, objective, transparent, and accurate. Also, it should present the achievement/failure to attain the determined goal and objective.

Thus, in implementing the financial performance and accountability for Papua Province, it should consider some principles as follow:

1) There should be strong commitment of the governor and all staffs of the related institution in the implementation of management and the implementation of special autonomy fund's mission to be accountable;

2) It must build a system that is able to assure the utilization of resources which is consistent with the applicable law and regulation.

3) Must be able to show the achievement level of determined goal and objective

4) Must be truthful, objective, transparent, and innovative.

References

[1] Anderson, J.C. and Narus, J.A, 1990. A model of distributor firm and manufacturer working partnerships. Journal of Marketing, Vol.4 No. 1, pp. $42-58$.

[2] Barney . 1991. Knowledge and Accountability: Outside's Directors'contribution in the corporate value chain. Centre for Innovation, Research and Competence in the Learning Economy (CIRCLE) Lund University P.O. Box 117, Sölvegatan 16, S-221 00 Lund, SWEDEN http://www.circle.lu.se/publications ISSN 1654-3149

[3] BPK RI, 2008. Laporan Hasil Pemeriksaan (audited) Atas Pengelolaan dan Pertanggungjawaban Dana Otonomi Khusus Tahun Anggaran 2008 Pada Provinsi Papua.

[4] BPK RI, 2011. Laporan Hasil Pemeriksaan Atas Pengelolaan dan Pertanggungjawaban Dana Otonomi Khusus Tahun Anggaran 2002-2010 Pada Provinsi Papua dan papua Barat.

[5] Child, J. and Faulkner, 1998. Strategies of Cooperation: Managing Alliances, Networks and Joint Ventures. Oxford University Press, Oxford.

[6] Das, T.K. and Teng, 2002. The dynamics of alliance conditions in the alliance development process. Journal of Management Studies, Vol. 39 No. 5, pp. 725-46.

[7] Das, S., Sen, P.K. and Sengupta, 2003. Strategic alliances: a valuable way to manage intellectual capital. Journal of Intellectual Capital, Vol. 4 No. 1, pp. 10-19.

[8] Das, T.K. and Teng, 2000. Instabilities of strategic alliances: an internal tensions perspective. Journal of Management Studies Organization Science, Vol. 11 No. 1, pp. 77-101.

[9] D'Aveni, 1995. Coping with hypercompetition: utilizing the new 7s's framework. Journal Academy of Management Executive, Vol. 9 No. 3, pp. 45-60.

[10] Halim, Abdul. 2008. Manajemen Keuangan Daerah, Pengelolaan Keuangan Daerah. Penerbit Unit Penerbit dan Percetakan STIM YKPN Yogyakarta, Hal 61.

[11] Hayadi.F and Kristiani, 2007, Analisis Kinerja Bidan Puskesmas Dalam Pelayanan Antenatal di Bengkulu Selatan, KMPK, WPS N0 11 April 2007 Yogyakarta 
[12] ICS, 2009. Jumpa Pers. Hasil Analisis APBD Provinsi Papua Tahun 2009. Jayapura.

[13] Jumingan. (2009). Analysis Financial Reports. Jakarta. Bumi Aksara.

[14] Moeller, Klaus, 2009. Intangible and financial performance: causes and effects. Journal of Intellectual Capital Vol. 10 No. 2, 2009 pp. 224-245 q Emerald Group Publishing Limited 1469-1930.

[15] Peraturan Daerah Khusus Provinsi Papua No 1, Tahun 2007 tentang Pembagian dan Pengelolaan Penerimaan Dalam Rangka Pelaksanaan Otonomi Khusus. Jayapura.

[16] Pemerintah Provinsi Papua, Parturan Daerah Nomor 5 Tahun 2006, Tentang Pembangunan Pendidikan Di Provinsi Papua.

[17] Undang-undang RI, Nomor 21. 2001. Tentang Otonomi Khusus Bagi Provinsi Papua.

[18] Pekman, Joe. 1998. Capital District Health Authority Research Ethics Board. http://www.governance.uottawa.ca/english/overview/o defi.htm (accessed August 25th, 2003) Cited in McDonald q.v. See also D. Zussman, Proposed Governance Structure for the Canadian Institutes of Health Research (Ottawa: Public Policy Forum, 1999). Version 2.11 August 28th, 2003

[19] Penrose. 1959. Examining the penrose effect in an international business context: the dynamics of japanese firm growth in u.s. Industries. We are grateful to Richard Levin, Alvin Klevorick, Richard Nelson, and especially Sidney Winter for providing us with the data from their paper in Brookings Papers on Economic Activity (1987). Published: 2003 URL: http://www.business.uiuc.edu/Working_Papers/papers/03-0113.pdf

[20] Sedarmayanti. 2003. Tata Kearsipan dengan Memanfaatkan Teknologi Modern. Bandung. Mandar Maju. Hal 64.

[21] Supoyo, Maryono. 2006. Studi Sistem Monitoring dan EvaluasiDalam Rangka Disentralisasi Pada Departemen Dalam Negeri Republik Indonesia. Disertasi. PDIM FE UB.

[22] Teece, 1998. Capturing value from knowledge assets: the new economy, markets for know-how, and intangible assets. California Management Review, Vol. 40 No. 3, pp. 55-79.

[23] Weber, Max.1960. Sekte-sekte Protestan dan Semangat Kapitalisme dalam Taufik Abdullah, editor. 1979. Agama, Etos Kerja dan Perkembangan Ekonomi. Jakarta: LP3ES.

[24] Wernerfelt, 1984. A resource-based view of the firm. Strategic Management Journal, Vol. 5 No. 2, pp. 171-80.

[25] Zaheer, A. and Venkatraman, N. (1995). Relational governance as an interorganizational strategy: an empirical test of the role of trust in economic exchange. Strategic Management Journal, Vol. 16 No. 5, pp. 373-92. 